\title{
PROYEK DEMOGRAFI DALAM BAYANG-BAYANG DISINTEGRASI NASIONAL: STUDI TENTANG TRANSMIGRASI DI GORONTALO, 1950-1960
}

\author{
Helman Manay \\ Progam Studi Pendidikan Sejarah Fakultas Keguruan dan Ilmu Pendidikan \\ Universitas Negeri Gorontalo \\ Alamat korespondensi: hmanay87@gmail.com \\ Diterima/ Received: 26 Maret 2016; Disetujui/ Accepted: 1 Agustus 2016
}

\begin{abstract}
The Republic of Indonesia faced variety problems related exploding population, national integration, and distribution of welfare in the postcolonial sovereignity 1949. In the context of new state formation there were three things inter-related as the most potential problems to threaten national integration. The unevennnes of well-being number of people in each island became one of important factors. Java as center for beuracracy since the Dutch colonial era, it has been the most densely populated island comparing of other islands that widely occupied by only few people. The government decided to continue colonization by a designed program named transmigration. It was expected to reduced Javanese residents significantly and placed them to another islands. Objectively, it aimed to develop their well-being condition. Menawhile, since 1958 when facing disintegration treatment, Indonesia had been more prominent in some areas, transmigration program geared to be knotted of national integration. In the end, the program must faced demographic and displacements problems in factual difficulties such as, financial, political conditions, and instability of national security at the time. Moving a third quarter of the Javanese population could not be executed well at that time. By using the method of historical research, this paper about to discover the realization of the transmigration program during 1950-1960 in Gorontalo conducted in the midst of instability of national security.
\end{abstract}

Keywords: transmigration, demographics, disintegration, Java, Gorontalo.

\begin{abstract}
Abstrak
Pascapengakuan kedaulatan oleh Belanda pada Desember 1949, Republik Indonesia dihadapkan pada beragam persoalan utamanya terkait ledakan jumlah penduduk, integrasi nasional dan pemerataan kesejahteraan. Dalam konteks negara baru ketiga hal di atas saling berkaitan, sebab masalah penduduk yang kebanyakan tidak sejahtera sangat potensial mengancam kesatuan bangsa. Persoalan berikutnya, selain kesejahteraan adalah tidak meratanya jumlah penduduk di masing-masing pulau. Jawa sebagai pusat pemerintahan sejak zaman kolonial Belanda menjadi pulau paling padat penduduknya, sementara pulau luar Jawa yang secara geografis lebih luas hanya ditempati oleh sedikit penduduk. Fakta inilah yang mendorong pemerintah memutuskan melanjutkan program politik etis dengan memperhalus istilah pemerintah kolonial Belnada, kolonisasi menjadi transmigrasi. Dengan transmigrasi diharapkan tekanan demografi di Jawa akan berkurang secara signifikan dan daerah baru yang menjadi tujuan penempatan akan berkontribusi terhadap peningkatan kesejahteraan secara nasional. Selain itu, sejak 1958 ketika ancaman disintegrasi semakin mengemuka di beberapa daerah, program transmigrasi diarahkan untuk menjadi simpul-simpul persatuan nasional. Pada akhirnya rencana besar pemindahan penduduk harus dihadakan pada kenyataan keuangan negara yang sulit dan kondisi politik serta keaman yang labail kala itu, sehingga rencana besar untuk memindahkan sepertiga penduduk Pulau Jawa tidak dapat terrealisasi. Dengan menggunakan metode penelitian sejarah tulisan ini hendak menelusuri realisasi program transmigrasi selama 1950-1960 di Gorontalo dan kaitannya dengan kondisi keamanan yang sangat labil saat itu.
\end{abstract}

Kata kunci: Transmigrasi, demografi, disintegarsi, Jawa, Gorontalo. 


\section{PENDAHULUAN}

Sebagai negara besar yang terdiri dari ribuan pulau dan ratusan suku bangsa, sejak awal Indonesia telah dihadapkan pada beragam persoalan, utamanya terkait ledakan jumlah penduduk, integrasi nasional, dan pemerataan kesejahteraan. Jauh sebelumnya hal itu juga menjadi problem pemerintah Hindia Belanda setelah berhasil menaklukan semua daerah yang awalnya tidak tunduk di bawah rezim Batavia. Masalah penting pada awal abad ke-20 adalah penurunan kesejahteraan penduduk pribumi di pulau Jawa, karena pertumbuhan jumlah penduduk yang tidak terkendali. Investigasi Menteri Urusan Jajahan, A. W. F. Idenburg pada 1902 melaporkan bahwa selama 20 tahun terakhir penduduk pulau Jawa telah bertambah empat puluh lima persen menjadi \pm 25.200 .000$ jiwa, sedangkan tanah sawah hanya bertambah dua puluh tiga persen (produktivitas dua puluh delapan persen). Jadi penghasilan rata-rata setiap orang pun menurun. Sementara jumlah petani yang tidak memiliki tanah bertambah (Niel, 1984: 52-53). Kenyataan di atas sejalan dengan pendapat Malthus, bahwa ledakan penduduk yang tidak terkendali akan menjadi ancaman serius terhadap persediaan pangan. Hal itu terjadi karena secara alamiah pertumbuhan penduduk cenderung bergerak mengikuti deret ukur, sedangkan persediaan bahan pangan bergerak mengikuti deret hitung (Hauser dan Duncon, 1958: 33).

Obsesi Pemerintah dalam kurun waktu 1950-1960 untuk melakukan transmigrasi penduduk dari pulau Jawa ke pulau-pulau lain hingga saat ini-selain alasan demografis dan ekonomi-tujuannya belum diketahui pasti. Meskipun demikian, hal ini mulai jelas ketika Keputusan Presiden No. 163 Tahun 1958 yang memuat tujuan pokok transmigrasi dikeluarkan. Dalam Kepres tersebut disebutkan bahwa tujuan transmigrasi adalah untuk meningkatkan keamanan, kemakmuran dan kesejahteraan rakyat, membangun daerah-daerah vital, serta mempererat rasa persatuan dan kesatuan bangsa. Dengan demikian, sangat jelas bahwa program transmigrasi tidak hanya terkait masalah demografi, tetapi menyangkut pula persoalan geopolitik dan geostrategis untuk kepentingan integrasi nasional.

Transmigrasi di Gorontalo pada 19501960 tergolong unik, sebab penempatannya diawali oleh sebuah surat permintaan pengiriman transmigran dari Jawa ke Paguyaman, Gorontalo. Surat tersebut ditulis oleh T. A. Lasahido (pengusaha perkebunan kelapa asal Sulawesi), ditujukan kepada Wakil Perdana Menteri selaku Koordinator Umum Program Transmigrasi. ${ }^{1}$ Hal tersebut cukup menarik mengingat secara geografis Gorontalo berada sangat jauh dari Pulau Jawa dan kondisi sarana transportasi masa itu relatif masih terbatas. Kondisi ini tentu sangat berbeda dengan pulau Sumatera dan Kalimantan yang relatif mudah dijangkau. Berdasarkan kenyataan tersebut, menarik mengungkap lebih lanjut pelaksanaan program transmigrasi di Gorontalo, terutama jika dikaitkan dengan masalah integrasi nasional yang banyak mengalami ujian pada periode 1950-1960. Oleh karena itu permasalahan yang dikaji adalah sebagai berikut. Pertama, pelaksanaan program transmigrasi di Indonesia, khususnya di Gorontalo pada 19501960; Kedua, relevansi konstelasi politik nasional dan daerah dengan program transmigrasi ke luar Jawa pada 1950-1960.

\section{METODE}

Penggunaan metode sangat penting dalam penelitian sejarah sebagai seperangkat aturan atau prinsip-prinsip yang secara sistematis dipergunakan untuk mencari dan menggunakan sumber-sumber sejarah. Metode sejarah adalah proses menguji dan menganalisa secara kritis rekaman dan peninggalan masa lampau. Dengan metode sejarah dapat direkonstruksi sebanyakbanyaknya peristiwa masa lampau manusia. Sejarah memiliki metode penelitian sendiri yang berbeda dengan ilmu-ilmu lain, secara umum dikenal dalam empat tahap, yakni heuristik, kritik, interpretasi, dan historiografi (Gotschalk, 1983: 18 dan 32). 
Sumber awal dari penelitian ini berasal dari arsip nasional terutama yang terangkum dalam Inventaris Arsip Kesekretariatan Negara Kabinet Perdana Menteri Tahun 1950-1959, Inventaris Arsip Kabinet Presiden RI 1950-1959, Daftar Pertelaan Arsip (DPA) Peraturan Perundang-undangan Dirinci Menurut Peraturan Pemerintah Periode 1950-1960, Daftar Pertelaan Arsip (DPA) Peraturan Perundang-undangan Dirinci Menurut Keputusan Presiden Periode 1950. Selain di arsip nasional, informasi tentang transmigrasi pada 1950-an terdapat juga di Arsip Daerah Jawa Tengah (ARDA Jateng) di Semarang. Terutama berupa foto dari persiapan, pemberangkatan dan daerah tujuan para transmigran asal Jawa Tengah pada tahun-tahun tersebut.

Selain sumber-sumber di atas, selama riset di Gorontalo, Peneliti juga memperoleh arsip berharga berupa foto-foto Gorontalo tahun 1950-1960 yang dikoleksi oleh Badan Arsip dan Perpustakaan Daerah Provinsi dan Kabupaten Gorontalo. Dokumen desa Sidodadi dan Sidomulyo baik berupa Rencana Pembangunan Jangka Menengah Desa (RPJMD) maupun monografi desa juga telah didapatkan Peneliti. Sebagai tambahan, koleksi pribadi-berupa foto dan dokumen tertulis-dari Darodji Marzuki (warga Sidomulyo, transmigran asal Banyuwangi, Jawa Timur) juga menambah khasanah sumber primer dalam penelitian ini. Akhirnya, sebuah buku tentang Provinsi Sulawesi yang diterbitkan Kementerian Penerangan pada 1953-ketika Sulawesi belum dimekarkan menjadi beberapa provinsi-juga sangat membantu melengkapi informasi lisan yang telah didapatkan.

Selain sumber-sumber primer di atas, sumber sekunder berupa buku dan artikel juga digunakan sebagai penunjang, utamanya bukubuku dan artikel yang secara khusus membahas transmigrasi pada masa tersebut. Hal ini sangat membantu dalam memberi pandangan umum tentang transmigrasi dan juga dapat dijadikan bahan pembanding (komparasi) dan pelengkap (koroborasi) terhadap sumber-sumber lain baik berupa arsip tekstual, koran, keterangan lisan maupun foto.

Setelah sumber-baik lisan maupun tulisan-telah didapatkan, maka tahap selanjutnya adalah proses pemeriksaan kevalidan dan keterandalan sumber-sumber tersebut. Dalam penelitian ini sumber-sumber diperiksa secara detail dengan menggunakan teknik kritik sumber yang ada dalam metode penelitian sejarah, yakni dengan mengajukan pertanyaan kritis terhadap sumber-sumber yang ada. Menurut Storey, pertanyaan sebaiknya diformulasikan dari $5 \mathrm{~W}$, yakni who (siapa), what (apa), why (mengapa), where (di mana) dan when (kapan) (Storey, 2011: 32-36). Selain teknik di atas, sumber-sumber tersebut juga dikomparasi dan dikoroborasikan satu sama lain guna mendapatkan otentisitas dan kredibilitas dari setiap sumber.

Setelah melalui tahap kritik, maka perlu dilakukan interpretasi terhadap sumber-sumber yang telah diyakini keabsahannya. Hal ini sangat dibutuhkan dalam mendalami setiap peristiwa, ketika kebijakan transmigrasi mulai diterapkan pemerintah Indonesia pada 1950. Interpretasi dilakukan dengan dua cara yakni analisis dan sintesis agar ditemukan sebuah narasi rasional yang menjadi corak umum dari karya sejarah. Dalam konteks penelitian ini, analisis berarti berusaha menguraikan setiap fakta sejarah yang ada dalam sumber, sehingga setiap kemungkinan dari fakta tentang transmigrasi Indonesia antara 1950-1960 dapat terungkap. Sementara itu, sintesis berarti menyatukan beberapa fakta dan data mengenai penerapan kebijakan transmigrasi di Indonesia, khususnya di Gorontalo pada masa tersebut, sehingga ditemukan kesimpulan tentang adanya maksud, tujuan dan penerapan kebijakan itu.

Tahap akhir atau puncak dari segala rangkaian penelitian sejarah adalah tahap interpretasi. Bahan-bahan yang telah dikumpulkan kemudian dirangkai menjadi sebuah kronologi cerita yang menarik sekaligus ilmiah. Oleh karena itu, dalam penelitian ini uraian cerita sejarah dilakukan dengan menggunakan tiga teknik dasar penulisan secara 
bersamaan yakni, deskripsi, narasi dan analisis. Hal ini dipandang cukup memadai dan dapat memenuhi tuntutan dalam penelitian serta penulisan sejarah.

\section{TUJUAN, RENCANA, DAN REALISASI PROGRAM TRANSMIGRASI}

Secara umum, gagasan pemindahan penduduk dilandasi oleh realitas kesenjangan jumlah penduduk antara satu wilayah dengan wilayah lain yang berdampak pada sektor ekonomi dan penghidupan rakyat. Pada 1951, secara eksplisit tujuan transmigrasi dilandasi oleh kepentingan pemerataan ekonomi seperti tercantum dalam Surat Keputusan Menteri Sosial untuk memakmurkan dan menyejahterakan rakyat dengan cara memindahkan penduduk dari daerah satu ke daerah lain.

Selain itu dijabarkan pula tugas dari Jawatan Transmigrasi sebagai penyelenggara utama program tersebut yakni:

1. Mengumpulkan penduduk di daerah yang padat untuk dipindahkan ke daerah-daerah lain;

2. Melakukan pembukaan tanah-tanah kosong dan hutan-hutan yang baik buat pemindahan penduduk (transmigrasi);

3. Memindahkan kaum transmigran dari tempat asalnya, ke tampat-tempat yang sudah dibuka menurut rencana yang telah disusun;

4. Membangun usaha-usaha bagi penghidupan transmigran di tanah transmigrasi;

5. Menjamin hidup kaum transmigran menurut batas yang ditentukan, sejak diberangkatkan dari tempat asalnya sampai mereka mendapat hasil penghidupan sendiri di tempat yang baru;

6. Memperbaiki keadaan para transmigran yang lama di tanah-tanah transmigrasi. (Inventaris ANRI No. 3460).

Tujuan dan tugas di atas, sepintas hanya berdasarkan kepentingan pemerataan ekonomi rakyat. Meskipun demikian, aspek-aspek lain tentu tidak dapat diabaikan terutama terkait dengan alasan politik dan keamanan. Demi alasan keamanan misalnya, Perdana Menteri
Wilopo membentuk Panitia Penampungan Bekas Corps Tjadangan Nasional (CTN) Sulawesi Selatan melalui Surat Keputusan No. 226/P.M./1952 tanggal 19 Agustus 1952. Tugas utama dari panitia ini adalah menjalankan usaha penyaluran kembali ke masyarakat, bekas anggota CTN Sulawesi Selatan yang telah melaporkan diri kepada pimpinan daerah militer VII. Konkretnya, panitia ini diberi tugas untuk melumpuhkan potensi pengacau, yakni bekas tentara yang dipimpin oleh Kahar Muzakar. Cara yang ditempuh adalah dengan menyediakan perumahan, makanan, mata pencaharian yang layak dan pelayanan kesehatan bagi mereka yang masih bisa dikembalikan ke kampung halamannya. Akan tetapi bagi yang tidak mungkin dikembalikan, maka akan dipindahkan ke daerah lain melalui program transmigrasi oleh Biro Rekonstruksi Nasional (BRN) (Inventaris ANRI No. 3473 dan 3461).

Perkembangan politik selama 1950-an akhirnya membawa perubahan besar dalam tujuan transmigrasi, yang semula hanya berdimensi sosial ekonomi, akhirnya diberi muatan kepentingan integrasi nasional pada 1958. Hal ini tercantum dalam surat keputusan presiden yang menetapkan tugas kementerian transmigrasi. Sejak saat itu, lapangan pekerjaan transmigrasi telah mengalami perubahan mendasar sebagai berikut.

1. Mempertinggi kemakmuran dan kesejahteraan seluruh rakyat, dengan jalan membuka dan mengusahakan tanah secara teratur serta mengadakan lain-lain usaha pembangunan dalam segala lapangan;

2. Mengurangi tekanan penduduk di daerahdaerah yang padat penduduknya untuk mencapai tingkat penghidupan yang layak dan mengisi daerah-daerah yang kosong atau tipis penduduknya untuk membuka sumbersumber alam;

3. Memperkokoh rasa persatuan dan kesatuan bangsa Indonesia;

4. Mencapai keamanan seluruh bangsa Indonesia serta memperbesar potensi pertahanan negara, dengan mengisi dan membangun daerah-daerah yang mempunyai 
arti vital, sehingga tercapai tingkatan ketahanan baik dalam lapangan sosial ekonomi, persatuan dan kesatuan bangsa, maupun pertahanan bagi daerah-daerah di seluruh wilaya Indonesia (Keppres 1950, Inventaris ANRI No. 1728).

Tujuan program transmigasi yang semakin luas di atas mencerminkan situasi nasional yang tidak stabil saat itu. Termasuk ancaman disintegrasi yang cukup serius, sehingga penyelesaiannya tidak hanya melalui jalan militer dan politik, tetapi juga melalui transmigrasi. Contoh konkret dari upaya ini adalah penempatan transmigrasi CTN di pulau Kalimantan pada 1952. Disebutkan bahwa selain karena tanah yang luas, belum adanya kesatuan militer di Kalimantan juga menjadi alasan Pemerintah menempatkan mantan tentara dan pejuang dari Jawa ke pulau itu. Demikian juga, dalam rangka meredam pemberontakan di Sulawesi Selatan, maka ditempuh jalan pemindahan (transmigrasi) mantan pengikut DI/TII Kahar Muzakar ke Dumoga, Sulawesi Utara dan pulau Seram, Maluku. Bahkan mereka dikelompokkan menjadi dua, yakni bagi yang menyerahkan diri akan ditempatkan di Dumoga (masih di wilayah pulau Sulawesi), sementara bagi yang ditangkap akan ditransmigrasikan ke luar pulau (Inventaris ANRI No. 3473). Pada perkembangan selanjutnya, terutama di zaman Orde Baru, transmigrasi umum dipilih sebagai salah satu cara memperkuat persatuan, bahkan terkesan menjadi upaya penyeragaman.

Seiring dengan penetapan tujuan, rencana-rencana besar pemindahan penduduk mulai disusun sejak akhir tahun 1950 dan efektif dijalankan satu tahun berikutnya. Khusus untuk transmigrasi mantan pejuang dan angkatan bersenjata didirikan Biro Rekonstruksi Nasional (BRN) dan Corps Tjadangan Nasional (CTN) pada awal 1951.

\section{Biro Rekonstruksi Nasional (BRN)}

BRN yang dibentuk pada 10 Februari 1951, segera memindahkan mantan pejuang yang tidak dapat ditampung dalam angkatan bersenjata. Sejak tahun 1951 telah dipindahkan sebanyak 1.100 kepala keluarga (KK) dari Jawa ke luar Jawa dan $100 \mathrm{KK}$ di internal pulau Sulawesi. Pada 1952 BRN merencanakan pemindahan $6.000 \mathrm{KK}$ (sekitar 24.000 jiwa) mantan pejuang dari Jawa ke pulau lainnya. Dari jumlah tersebut, hanya $3.700 \mathrm{KK}$ yang berhasil dipindahkan. Melihat kenyataan itu, target pada 1953 diturunkan menjadi 5.000 KK. Angka ini dianggap realistis dan terbukti dapat diwujudkan, bahkan dilampaui. Hingga Juli 1953 telah ditransmigrasikan sekitar $6.150 \mathrm{KK}$, surplus $1.150 \mathrm{KK}$ dari target capaian (Kabinet Perdana Menteri Tahun 1950-1959, ANRI: Inventaris Arsip Kesekretariatan Negara No. 3470).

\section{Corps Tjadangan Nasional (CTN)}

CTN merupakan lembaga yang dibentuk pada 28 Maret 1951 untuk mengurus, mengatur dan memelihara anggota dan mantan anggota angkatan perang. Meskipun mirip dengan BRN namun wilayah kerjanya hanya dikhususkan pada mantan angkatan bersenjata, tidak meliputi mantan pejuang secara keseluruhan. Meskipun lembagai ini baru dibentuk pada 1951, sebenarnya pemindahan bekas angkatan perang telah dilakukan sejak 1950 oleh Korps Tentara yang berhasil mentransmigrasikan $1.700 \mathrm{KK}$ dari Jawa ke Sumatera dan Kalimantan. Selama 1951, setelah CTN terbentuk, berhasil dipindahkan sekitar $2.170 \mathrm{KK}$ anggota CTN dengan destinasi yang sama (ANRI, Inventaris Arsip Kesekretariatan Negara No. 3470).

Pada 1952 direncanakan pemindahan 38 Kompi dari Jawa ke Kalimantan, namun hingga akhir tahun, baru dapat dipindahkan 7 Kompi atau sekitar 1.800 KK. Satu tahun berikutnya, terjadi kesepakatan antara berbagai lembaga yang menangani transmigrasi. Destinasi transmigran CTN hanya pulau Kalimantan, sehingga pulau Sumatera, Sulawesi dan pulaupulau lainnya tidak lagi menjadi tujuan penempatan. Pada tahun itu direncanakan pemindahan $8.000 \mathrm{KK}$ (sekitar 32.000 jiwa) dari Jawa ke Kalimantan, tetapi hingga bulan Juli 
realisasinya baru $4.270 \mathrm{KK}$. Secara keseluruhan antara 1951 sampai 1953, berhasil dipindahkan 20.078 jiwa, melalui lembaga ini (ANRI, Inventaris Arsip Kesekretariatan Negara No. 3471).

Sementara itu, program pemindahan penduduk secara umum dan berkesinambungan merupakan tanggung jawab Jawatan Transmigrasi. Oleh karena itu, sejak 1950 lembaga ini telah menetapkan rencana-rencana besar, terutama ketika Ir. A.H.O. Tambunan menjabat sebagai Kepala Jawatan. Planning Tambunan utamanya adalah mengurangi penduduk pulau Jawa hingga sepertiga dari jumlah yang ada dalam jangka waktu 15 tahun (1950-1965). Rencana ini masih dianggap kurang ambisius, sehingga pada 1953 ditingkatkan menjadi Rencana Tiga Puluh Lima Tahun Tambunan (1953-1987), yang bertekad memindahkan 48.675 .000 jiwa penduduk dari Jawa, Bali dan Madura ke pulau lainnya (Oey dan Astika, 1982:30-31).

Namun demikian, realisasi pemindahan penduduk oleh Jawatan Transmigrasi sangat jauh dari yang telah direncanakan. Sejumlah 31.000.000 jiwa yang seharusnya dipindahkan menurut rencana lima belas tahun Tambunan di awal dekade 1950-an sama sekali tidak sesuai harapan. Demikian pula dengan rencana 10 tahun Pemerintah di akhir dekade 1950-an, sangat jauh dari kenyataan (ANRI, Inventaris Arsip Kesekretariatan Negara No. 3471). Pada Tabel 1 dan 2 menunjukkan bahwa, realisasi pemindahan tidak menyentuh angka setengah dari rencana yang telah disusun sebelumnya.

Tabel 1. Jumlah Transmigran di Indonesia 1950-1960 (dalam Jiwa).

\begin{tabular}{cccc}
\hline No. & Tahun & $\begin{array}{c}\text { Jumlah } \\
\text { Keluarga }\end{array}$ & Jumlah Jiwa \\
\hline 1. & 1950 & 23 & 77 \\
2. & 1951 & 790 & 2.951 \\
3. & 1952 & 3.855 & 17.605 \\
4. & 1953 & 9.240 & 40.009 \\
5. & 1954 & 8.409 & 29.738 \\
6. & 1955 & 5.500 & 21.389 \\
7. & 1956 & 6.091 & 25.519 \\
8. & 1957 & 4.421 & 20.045 \\
\hline
\end{tabular}

\begin{tabular}{cccc}
\hline 9. & 1958 & 4.799 & 20.063 \\
10. & 1959 & 11.439 & 46.096 \\
11. & 1960 & 5.625 & 22.078 \\
& Total & 60.192 & 246.110 \\
\hline \multicolumn{4}{r}{ Sumber: Oey dan Astika, 1982: 34. }
\end{tabular}

Sumber: Oey dan Astika, 1982: 34.

Tabel 2. Jumlah Transmigran Menurut Daerah Tujuan, Periode 1951 hingga Juni 1974.

\begin{tabular}{clcc}
\hline No & Daerah Tujuan & $\begin{array}{c}\text { Jumlah } \\
\text { Keluarga }\end{array}$ & $\begin{array}{c}\text { Jumlah } \\
\text { Jiwa }\end{array}$ \\
\hline 1. & Aceh & 140 & 695 \\
2. & Sumatera Utara & 3.343 & 11.480 \\
3. & Sumatera Barat & 3.415 & 14.723 \\
4. & Ria & 794 & 3.699 \\
5. & Jambi & 2.563 & 11.875 \\
6. & Sumater Selatan & 49.096 & 206.656 \\
7. & Bengkulu & 1.580 & 7.415 \\
8. & Lampung & 47.658 & 204.225 \\
9. & Transmigran Lokal & 75 & 108 \\
10. & Banten Lampung & 1.299 & 5.032 \\
11. & Nusa Tenggara & 168 & 654 \\
12. & Kalimantan Barat & 2.923 & 12.146 \\
13. & Kalimantan Tengah & 2.075 & 9.548 \\
14. & Kalimantan Selatan & 5.091 & 22.438 \\
15. & Kalimantan Timur & 6.114 & 25.433 \\
16. & Sulawesi Utara & 2.443 & 10.334 \\
17. & Sulawesi Tengah & 4.878 & 21.923 \\
18. & Sulawesi Selatan & 5.240 & 24.207 \\
19. & Sulawesi Tenggara & 2.139 & 9.896 \\
20. & Maluku & 782 & 2.764 \\
21. & Irian Jaya & 355 & 1.500 \\
& Jumlah Total & 142.180 & 606.751 \\
\hline & Sumber: Oey dan Astika, $1982: 34$. \\
\hline
\end{tabular}

Kenyataan yang tergambar pada tabel di atas menunjukkan bahwa antara 1950-1960 merupakan masa ketika ide-ide besar disemai dan harapan-harapan tinggi digantungkan dalam semua bidang kehidupan bernegara, termasuk upaya pemindahan penduduk. Meskipun demikian, kadang-kadang ekspektasi tersebut tidak diiringi dengan kesadaran akan kenyataan sebagai negara baru yang kekurangan dalam semua bidang (Vickers, 2011: 203-205). Khusus bidang transmigrasi, Pemerintah tampaknya kurang memperhatikan bahwa, sebelum memindahkan penduduk banyak persiapan yang 
tidak boleh diabaikan. Pembukaan tanah, pembuatan jalan, pembangunan bendungan untuk irigasi, penyediaan infrastruktur lainnya adalah beberapa hal penting yang tidak bisa dilepaskan dari program transmigrasi. Selain itu, psikologi masyarakat juga perlu disesuaikan dengan lingkungan yang baru, sebab tidak semua kondisi tanah sama suburnya dengan lembah dan dataran tinggi di Jawa. Tanpa perhatian memadai atas aspek-aspek tersebut, sulit mengharapkan hasil yang positif dari program transmigrasi, baik di bidang demografi, politik terlebih lagi ekonomi (ANRI, Inventaris Arsip Kesekretariatan Negara No. 3459). ${ }^{2}$

\section{TRANSMIGRASI DI GORONTALO}

Wilayah Gorontalo yang dijadikan tujuan awal program transmigrasi adalah dataran Paguyaman. Sebuah daerah yang cukup luas, sekitar $65 \mathrm{~km}$ sebelah barat Kota Gorontalo. Daerah ini dipilih selain karena tersedia cukup banyak lahan, kondisi topografinya secara umum tidak jauh berbeda dengan kondisi di pulau Jawa. Dataran yang cocok untuk persawahan ditambah ketersediaan air yang cukup menjadikan Paguyaman sangat ideal untuk eksperimentasi awal program transmigrasi di wilayah Gorontalo. Selain itu, jarak dari kota dan pelabuhanpelabuhan penting di Gorontalo juga relatif dekat dibandingkan dengan dataran lainnya (Wawancara Yunus Taidi, 1 Maret 2013). Gambar 1 menunjukkan posisi strategis dataran Paguyaman sehingga menjadi pilihan pertama dalam penempatan transmigran.

Pada 1951, dua tahun sebelum realisasi program, T.A. Lasahido, seorang pegusaha perkebunan kelapa asal Sulawesi yang bermukim di Jakarta pernah menulis surat kepada Wakil Perdana Menteri selaku Koordinator Nasional Program Transmigrasi. Maksud utama surat tersebut adalah meminta tenaga kerja dari Jawa untuk mengelola perkebunan kelapa di Pulau Una-Una (dekat Gorontalo), yang terbengkalai karena kekurangan buruh. Meskipun demikian, dua lembar terakhir suratnya menyarankan agar pemerintah mengirimkan transmigran dari Jawa untuk mengolah tanah yang luas di Paguyaman. Hal ini dimaksudkan untuk memproduksi beras dengan sistem persawahan. Perlu diketahui bahwa saat itu wilayah Sulawesi Utara, Tengah, dan Kepulauan Banggai serta Maluku masih mengimpor beras dari Sulawesi Selatan dan pulau Jawa (ANRI, Inventaris Arsip Kesekretariatan Negara No. 3461). ${ }^{3}$

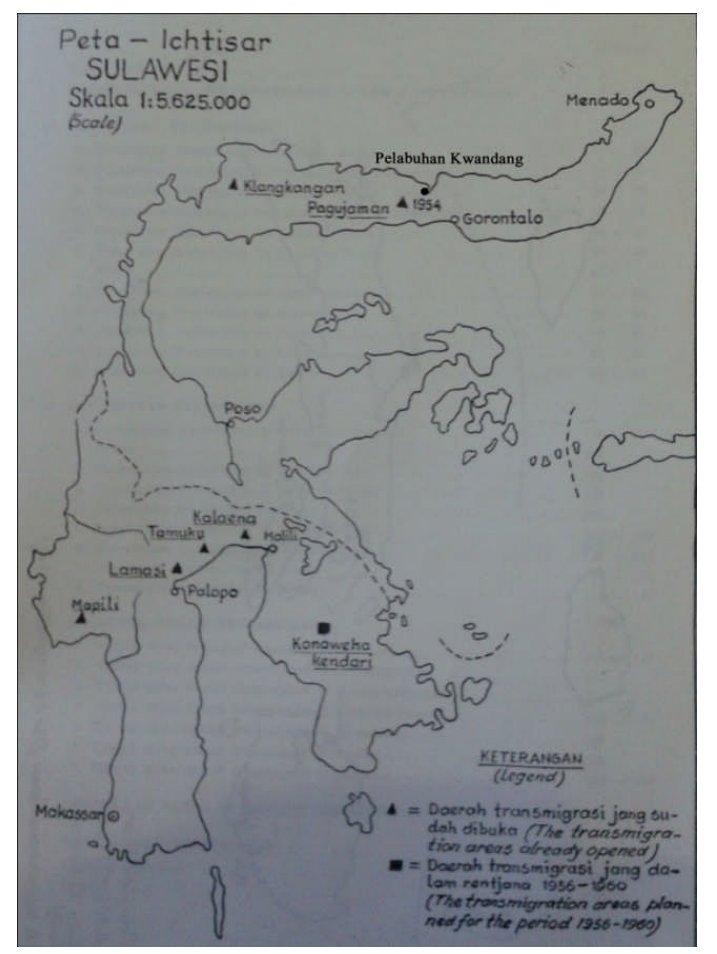

Gambar 1. Posisi Dataran Paguyaman yang tidak jauh dari Kota Gorontalo dan Pelabuhan Kwandang

(Sumber: Djawatan Transmigrasi, 1956)

Terdapat delapan poin pemikiran penting T.A. Lasahido mengenai pentingnya transmigrasi di Paguyaman. Delapan poin itu secara umum terkait dengan keuntungan dari segi geografis, topografis dan ekonomi bagi para transmigran (ANRI, Inventaris Arsip Kesekretariatan Negara No 3461). ${ }^{4}$

Sebelum adanya surat tersebut, pada Oktober 1951 Jawatan Transmigrasi Propinsi Sulawesi juga telah menyelidiki wilayah-wilayah di Sulawesi yang cocok untuk penempatan transmigran, termasuk di Gorontalo. Berdasarkan inspeksi yang dilakukan, terdapat dua lokasi yang cocok untuk transmigrasi yakni, 
dataran Pinogu di bagian timur Kota Gorontalo dengan luas sekitar 5.000 ha dan dataran Paguyaman di sebelah barat Kota Gorontalo, luasnya sekitar 60.000 ha (Kementerian Penerangan RI, 1953). Pada akhirnya hanya wilayah Paguyaman yang dijadikan sebagai objek transmigrasi. Mungkin karena dataran Pinogu tidak begitu luas dan telah banyak penduduk lokal yang bermukim di tempat itu.

Tiga tahun sebelum transmigran dari Jawa ditempatkan di Paguyaman, Pemerintah Daerah Gorontalo yang disubsidi oleh Negara Indonesia Timur (NIT) telah menyelenggarakan pemindahan penduduk. Sebanyak 288 jiwa telah dipindahkan dari wilayah kota Gorontalo dan sekitarnya ke dataran Paguyaman (Kementerian Penerangan RI, 1953:467).

Selama 1952 hingga paruh pertama 1953 penyelidikan dan berbagai persiapan penempatan transmigran dari Jawa telah dilakukan. Akhirnya pada September 1953 rombongan pertama dari Blitar dan Tulungagung, Jawa Timur tiba di lokasi tersebut. Mereka menempati bedeng (barak) yang disediakan Pemerintah sebagai tempat tinggal sementara, sebelum dapat membuat rumah di lahan masing-masing (Wawancara dengan Sutrisna, 5 Maret 2013). Satu bulan setelah kedatangan rombongan pertama, rombongan kedua yang berasal dari Bandung, Jawa Barat tiba pada 10 Oktober 1953. Rombongan ini adalah kelompok transmigrasi BRN, yakni mantan pejuang dari Jawa Barat yang tidak dapat ditampung dalam korps tentara nasional. Pimpinan rombongan adalah Sukandar, seorang purnawirawan divisi Siliwangi (Wawancara dengan Mardzuki dan Sutrisna, 5 Maret 2013).

Tidak seperti selang waktu antara rombongan satu dan dua yang singkat, kedatangan rombongan tiga butuh waktu beberapa bulan setelah rombongan dua. Transmigran yang berasal dari daerah bekas Keresidenan Besuki dan Surabaya, Jawa Timur ini, baru tiba di Paguyaman pada Mei 1954. Rombongan tersebut dipimpin oleh seorang bernama Sudayin. Secara keseluruhan rombongan ini terdiri dari 336 jiwa yang terbagi dalam 85 KK (Djawatan Transmigrasi, 1956:112). Hingga sampai di lokasi penempatan, perjalanan yang ditempuh tidak berbeda dengan rombongan sebelumnya, yakni melalui Tanjung Perak ke Pelabuhan Kwandang dan selanjutnya menempuh jalur darat hingga sampai di Paguyaman. Setelah tiba di lokasi, mereka ditempatkan di bedeng yang sama dengan dua rombongan sebelumnya (Wawancara dengan Sutrisna, 5 Maret 2013).

Setelah penempatan transmigran yang cukup intens antara 1953 sampai awal 1955. Pemerintah pun kembali melanjutkan program ini. Tercatat ada empat rombongan yang ditempatkan. Kelompok transmigran yang dipindahkan pada gelombang ini kebanyakan berasal dari dari daerah-daerah di Jawa Tengah dan Daerah Istimewah Yogyakarta (DIY) (Wawancara dengan Sutiwar, 1 Juli 2013). Tabel 3 menunjukkan jumlah transmigaran dari pulau Jawa yang ditempatkan di wilayah Gorontalo (Paguyaman) selama kurun waktu 1950-1960.

Setelah tiba di lokasi baru, para transmigran menempati barak penampungan sementara, guna menunggu pembagian tanah yang telah dijanjikan. Bantuan berupa alat-alat pertanian dan pertukangan telah dibagikan pada saat keberangkatan. Selama berada di tempat tersebut, semua kebutuhan pokok merekaterutama makanan-dipenuhi oleh Pemerintah. Untuk sebagian besar transmigran, bantuan berupa alat-alat pertanian dan pertukangan tidak diterima secara gratis, karena mereka harus mengembalikan berangsur-angsur kepada Pemerintah jika usaha pertanian telah berhasil. Pemerintah juga menyediakan dana yang dapat dipinjam oleh transmigran dan harus dikembalikan dalam jangka waktu hingga 15 tahun. Angsuran pertama pengembalian setidaktidaknya diberikan pada panen ketiga atau tiga tahun setelah kedatangan. Aturan ini berlaku bagi semua, baik untuk transmigran umum maupun mantan pejuang (ANRI, Inventaris Arsip Kesekretariatan Negara No. 3463). ${ }^{5}$ 
Tabel 3. Penempatan Transmigran di Paguyaman, 1950-1960

\begin{tabular}{|c|c|c|c|c|c|}
\hline \multirow{2}{*}{ No } & \multirow{2}{*}{ Daerah (Keresidenan) } & \multicolumn{3}{|c|}{ Tahun } & \multirow{2}{*}{$\begin{array}{l}\text { Jumlah } \\
\text { (Jiwa) }\end{array}$} \\
\hline & & 1953 & 1954 & 1955 & \\
\hline 1. & Priangan (Jawa Barat) & $65 \mathrm{KK}$ & & & 182 \\
\hline 2. & $\begin{array}{l}\text { Banyumas (Jawa } \\
\text { Tengah) }\end{array}$ & & & $53 \mathrm{KK}$ & 244 \\
\hline 3. & Kedu (Jawa Tengah) & & & $45 \mathrm{KK}$ & 186 \\
\hline 4. & $\begin{array}{l}\text { Surakarta (Jawa } \\
\text { Tengah) }\end{array}$ & & & $30 \mathrm{KK}$ & 108 \\
\hline 5. & Yogyakarta (DIY) & & & $40 \mathrm{KK}$ & 143 \\
\hline 6. & Surabaya (Jawa Timur) & & $3 \mathrm{KK}$ & $10 \mathrm{KK}$ & 48 \\
\hline 7. & Besuki (Jawa Timur) & & $82 \mathrm{KK}$ & $47 \mathrm{KK}$ & 550 \\
\hline 8. & Madiun (Jawa Timur) & & & $30 \mathrm{KK}$ & 107 \\
\hline 9. & Kediri (Jawa Timur) & $24 \mathrm{KK}$ & $\begin{array}{l}100 \\
\mathrm{KK}\end{array}$ & $47 \mathrm{KK}$ & 636 \\
\hline Jum & h total (KK dan jiwa) & 89 & 185 & 302 & 2.204 \\
\hline
\end{tabular}

Pekerjaan pertama yang dilakukan transmigran adalah membuka hutan belantara yang telah ditetapkan petugas dari Djawatan Transmigrasi sebagai lahan pemukiman dan pertanian. Pohon-pohon besar ditebang menggunakan gergaji tangan yang digerakan dua orang, kemudian dibentuk sebagai bahan dasar bangunan rumah. Proses ini selain dilakukan warga trans, juga oleh tenaga-tenaga yang disewa Djawatan Transmigrasi. Setelah penebangan selesai, petugas Djawatan dan warga, kemudian melakukan pengukuran tanah yang akan dibagikan untuk masing-masing kepala keluarga. Besarnya tanah yang diberikan adalah 0,25 hektar untuk perumahan, 1 hektar untuk persawahan dan 0,75 hektar untuk perladangan atau lahan cadangan.

Pada umumnya transmigran memilih menjadi petani sawah dan tanaman-tanaman yang cepat berbuah (menghasilkan). Hal ini berbeda dengan warga lokal Gorontalo di desadesa sekitarnya yang membudidayakan tanaman kelapa dan hanya menanam sedikit bahan makanan (padi dan jagung) di lahan-lahan mereka. Selain itu, pola pertanian yang diterapkan juga berbeda. Warga transmigran mengolah tanah persawahan dan perladangan tetap sepanjang tahun, sementara warga lokal menggunakan sistem tebang bakar (huma) atau lahan berpindah.

Kondisi tanah yang menjanjikan keberhasilan, dan memang terbukti demikian, tidak serta merta membuat semua transmigran betah di lokasi baru ini. Ada beberapa anak transmigran yang memilih merantau ke kota Gorontalo dan beberapa daerah di Sulawesi, karena tidak tahan dengan hutan belantara yang cukup jauh dari keramaian. Sutrisna adalah salah satunya. Pada 1955 ia meninggalkan daerah transmigrasi, kemudian merantau ke Moutong dan Parigi, Sulawesi Tengah. Di tempat yang baru itu, ia sempat bekerja beberapa tahun sebagai mandor di Yayasan Kopra (YK), sebelum akhirnya tentara Permesta menguasai wilayah tersebut pada 1958 (Wawancara dengan Sutrisna, 5 Maret 2013). Demikian juga dengan Yatmiran, yang merantau ke Kota Gorontalo demi mendapatkan pekerjaan berupah. Ia berpandangan bahwa hidup di daerah transmigrasi yang dikelilingi hutan belantara tidak menjanjikan apa pun. Terlebih untuk mendapatkan uang. Selama berada di Kota Gorontalo, ia sempat bekerja serabutan sebelum akhirnya menjadi karyawan di Djawatan Kehutanan Gorontalo. Ia hanya beberapa tahun bekerja di tempat ini, karena pada 1958 terpaksa harus pulang ke lokasi transmigrasi, disebabkan 
munculnya desas desus yang menyatakan bahwa orang-orang Jawa akan ditangkap dan dibunuh oleh tentara Permesta (Wawancara dengan Sartim, 20 Maret 2013).

Fakta-fakta di atas membuktikan bahwa pada awal kedatangan di lokasi penempatan, para transmigran hidup dalam kondisi yang cukup sulit. Banyak transmigran merasa kecewa karena menjumpai kenyataan tidak sesuai harapan dan janji pemerintah. Daerah penempatan adalah hutan belantara yang belum terbuka baik untuk pemukiman maupun pertanian. Meskipun demikian, tidak ada pilihan lain bagi mereka, dan bertahan adalah jalan satusatunya yang paling rasional. Keinginan kembali ke tanah asal tentu sangat kuat. Namun mewujudkan mimpi itu adalah hal mustahil, sebab untuk sampai ke daerah transmigrasi, mereka harus berhutang pada Pemerintah. "Mau apa lagi selain bertahan, walaupun banyak yang tidak sesuai janji”, demikian ungkapan salah seorang transmigran (Wawancara dengan Sukup, 24 Juli 2013). Dengan kerja keras dan kesungguhan, akhirnya pada 1960 semua lokasi telah dibuka dan menjadi dua buah desa yakni Sidomulyo dan Sidodadi.

Selain pengaturan lahan pemukiman, aspek pendidikan juga menjadi perhatian Pemerintah guna menampung anak-anak transmigaran, baik yang sebelumnya telah bersekolah di daerah asal maupun yang belum. Pendidikan dasar bagi anak-anak transmigran pada akhirnya diselenggarakan meski dihadapkan pada berbagai keterbatasan, terutama di bidang sumber daya manusia (guru) dan infrastruktur (bangunan dan fasilitas penunjang lainnya). Dengan memanfaatkan barak yang telah kosong, pada 1955 Sekolah Rakyat (SR) resmi dibuka untuk kelas I (satu) hingga kelas V (lima) (Wawancara dengan Marzuki, 3 Maret 2013). Kepala sekolah pertama yang memimpin sekolah itu adalah Murad Kakoe. Memperhatikan namanya, nampaknya beliau adalah orang Gorontalo. Salah satu murid kelas 1 angkatan pertama adalah Darodji Marzuki yang kala itu berusia 7 tahun. Ia mengenang bahwa saat itu tidak ada siswa yang berasal dari warga lokal. Semua adalah anak-anak transmigran. Bagi anak-anak yang ingin melanjutkan sekolah ke jenjang lebih tinggi, mereka harus ke Kota Gorontalo di bagian timur yang jaraknya sekitar $65 \mathrm{~km}$ atau ke daerah Tilamuta di sebelah barat pemukiman transmigran yang berjarak sekitar $45 \mathrm{~km}$ (Wawancara dengan Yatmiran, 6 Maret 2013).

Di daerah baru, para transmigran datang membawa serta tradisi dan budaya daerah mereka masing-masing. Secara eksternal, hubungan antara para transmigran dengan masyarakat lokal di masa-masa awal penempatan di Gorontalo tidak berjalan dengan baik. Para transmigran umumnya kesulitan berinteraksi dengan penduduk lokal, utamanya karena kendala perbedaan bahasa. Kebanyakan warga lokal saat itu tidak bisa berbahasa Indonesia. Demikian juga dengan warga transmigran, sehingga sikap saling curiga tidak terhidarkan. Bahkan pernah menimbulkan konflik yang berujung pembunuhan terhadap seorang warga lokal oleh beberapa transmigran asal Jawa Barat (Wawancara dengan Marzuki, 6 Maret 2013). Beruntung kejadian itu tidak mencuat menjadi konflik berkepanjangan seperti yang terjadi di daerah lain pada dekade tersebut (Abdullah dan Abdurrachman, 2011:290-291).

Seiring berjalannya waktu, kondisi tersebut dapat diatasi. Terdapat berbagai faktor yang mendukung terjadinya pembauran dan integrasi di antara para transmigran dan penduduk lokal, antara lain: pertama, kesamaan beragama Islam. Kesamaan agama memungkinkan terjadinya interaksi yang lebih baik, terutama pada hari-hari besar keagamaan; kedua, dibangunnya tempat-tempat umum seperti pasar dan balai pengobatan yang menjadikan intensitas interaksi antara transmigran dan penduduk lokal semakin tinggi; ketiga, tidak adanya konflik agraria seperti di daerah lain, karena para transmigran dan penduduk lokal memiliki cara yang berbeda dalam memilih lahan, tanaman dan pembudidayaannya.

Sementara itu secara internal, antar para transmigran Jawa berusaha mengembangkan 
budaya dan tradisi mereka di daerah tempat tinggal yang baru. Di bidang kesenian dan kebudayaan, mereka secara mandiri membentuk sanggar-sanggar kesenian seperti sanggar kesenian Wayang Wong, Wayang Kulit, Prabo Loro, Jenger, Ludruk, Reyog, Ketoprak, dan seni bela diri Pencak Silat. Hari-hari besar dalam agama Islam juga dirayakan dengan tradisi seperti kelaziman di daerah asal transmigran (Wawancara dengan Marzuki, 3 dan 6 Maret 2013). Hal ini menjadi salah satu ciri khas transmigran dari Jawa yang selalu membawa unsur-unsur budaya ke tanah perantauan. Dapat dipastikan bahwa hampir semua wilayah yang ditempati atau dijadikan pemukiman oleh kelompok masyarakat Jawa perantauan pasti melestarikan tradisi-tradisi dari tanah asalnya. Kenyataan ini tidak hanya terjadi pada pemukiman-pemukiman orang Jawa di Indonesia, tetapi juga di luar negeri, seperti Suriname yang pernah dijadikan penempatan ribuan kuli dari Jawa sejak pertengahan abad ke19 (Suparlan, 1972: 189-190).

Dalam bidang ekonomi, hasil panen yang mulai surplus 2-3 tahun setelah kedatangan, memberi harapan perbaikan kehidupan warga transmigran di masa mendatang. Untuk memasarkan hasil-hasil tersebut mereka harus berjalan sejauh lebih dari $3 \mathrm{~km}$ untuk mencapai pasar yang berada di desa Tangkobu di bagian selatan. Hingga 1956 aktivitas tersebut masih rutin dilaksanakan, namun sejak dibukanya pasar di wilayah pemukiman transmigran pada 1956, maka aktivitas ekonomi mulai lancar. Lokasi pasar pertama berdekatan dengan balai pengobatan, yakni di bagian selatan yang berbatasan dengan desa penduduk lokal Gorontalo (Sekretariat Desa Sidomulyo, 2012). Selain berfungsi ekonomi, pasar juga berperan sebagai sarana peningkatan interaksi sosial warga transmigran dengan penduduk lokal, sehingga hubungan menjadi semakin akrab. Banyak pedagang dan warga Gorontalo yang melakukan aktivitas ekonomi di pasar ini. Bahkan dalam perkembangannya beberapa pedagang Gorontalo kemudian bermukim di sekitar pasar tersebut (Wawancara dengan Sukardi, 20 Maret 2013).

\section{BERTRANSMIGRASI DI TENGAH ANCAMAN DISINTEGRASI}

Seperti telah dikemukakan sebelumnya bahwa pergolakan daerah yang dampaknya sangat dirasakan di Gorontalo adalah pemberontakan gerakan Perjuangan Rakyat Semesta (Permesta). Awalnya gerakan ini hanya bermaksud untuk menuntut keseimbangan pembangunan antara pusat dan daerah. Kondisi tersebut berubah setelah berbagai tuntutan yang disuarakan Permesta tidak segera ditanggapi oleh Pemerintah Pusat. Pemberontakan oleh Permesta kemudian terjadi di berbagai daerah. Seperti di wilayah Gorontalo, khususnya Sidomulyo dan Sidodadi, kebijakan Permesta cukup memberatkan transmigran. Mereka diwajibkan menggali lubang-lubang, semacam mini bungker di sisi kiri-kanan jalan trans Sulawesi-tidak jauh dari Sungai Paguyamanyang direncanakan sebagai pos penyergapan pasukan TNI. Selain itu, mereka juga mengerahkan anak-anak sekolah untuk menancapkan bambu runcing sebagai ranjau di sekitar lokasi tersebut, untuk mengantisipasi tentara payung dari TNI yang akan mendarat (Wawancara dengan Marzuki, 6 Maret 2013). Puncak dari semua itu adalah instruksi bagi semua transmigran untuk berjalan kaki sejauh 7 $\mathrm{km}$ dan berkumpul di lapangan pusat kecamatan Paguyaman. Transmigran di atas usia 7 tahun, kecuali yang telah pikun, wajib ikut dalam rombongan, termasuk orang-orang sakit yang harus ditandu agar bisa ikut berkumpul (Wawancara dengan Sawiyem, 1 Maret 2013). Pengumpulan warga Sidodadi dan Sidomulyo di sebuah tanah lapang, tidak lain adalah untuk mempermudah eksekusi (pembantaian) massal terhadap orang-orang Jawa di Gorontalo.

Sebelum eksekusi dilaksanakan, Kapten Sigar (seorang Permesta dari Minahasa) berpidato di depan khalayak, termasuk orang Gorontalo yang dikumpulkan terpisah dari orang Jawa. Hal utama yang disampaikan adalah 
keburukan-keburukan Pemerintah Pusat, termasuk Presiden Soekarno. Namun demikian, rencana kejam tersebut akhirnya tidak terlaksana, karena Kapten Sondakh yang ditunggu kehadiriannya tidak bisa datang. Pasukan Rimba pro NKRI (Negara Kesatuan Republik Indonesia), pimpinan Nani Wartabone kemudian melakukan penyerangan. Para transmigran akhirnya berhasil diselamatkan dan dapat kembali lagi ke rumah masing-masing. Pasca kejadian itu, Nani Wartabone yang berasal dari etnis Gorontalo dianggap sebagai penyelemat warga transmigran. Sejak saat itu, ikatan persaudaraan antara orang Jawa dan Gorontalo terjalin semakin baik dalam bingkai Negara Kesatuan Republik Indonesia (NKRI) (Wawancara dengan Wijoyo, 1 Maret 2013).

Peristiwa kegagalan rencana pembantaian transmigran disadari atau tidak, telah menjadi salah satu simpul yang menguatan integrasi nasional, terutama antara warga lokal Gorontalo dan pendatang dari Jawa. Hal ini cukup penting, mengingat pada awal kedatangan, para transmigran mengalami masalah dalam berinteraksi dengan warga lokal. Pembebasan para transmigran oleh Pasukan Rimba pimpinan Nani Wartabone dari percobaan pembantaian yang diprakarsai Permesta, menjadi perekat hubungan antara penduduk lokal (etnis Gorontalo) dan pendatang (etnis Jawa dan Sunda).

\section{SIMPULAN}

Berdasarkan uraian di atas, dapat dilihat bahwa program transmigrasi yang diselenggarakan oleh Pemerintah Indonesia dalam kurun waktu 19501960 merupakan salah satu jalan untuk mengatasi berbagai permasalahan sosial ekonomi dan politik keamanan nasional yang sedang dihadapi saat itu. Meskipun secara umum hasilnya tidak sesuai dengan yang telah direncanakan, namun transmigrasi di Gorontalo khususnya, relatif berjalan sesuai dengan yang diharapkan. Dalam kasus penempatan orang Jawa di Gorontalo oleh Pemerintah, pada kenyataannya telah menjadi salah satu bukti keberhasilan proses upaya mempererat persatuan dan kesatuan bangsa (integrasi nasional), antara Jawa dan Luar Jawa melalui program transmigrasi.

Transmigrasi di Gorontalo difokuskan pada wilayah Paguyaman. Di tempat ini, antara 1953 sampai 1955 telah menerima para transmigran yang berasal dari sembilan rombongan penduduk sipil dari daerah-daerah di Jawa Timur dan Jawa Tengah, serta satu rombongan transmigran mantan pejuang dari Jawa Barat. Proses adaptasi atara masyarakat transmigran atau pendatang dengan penduduk asli berlangsung dengan lancar dan damai. Terdapat empat media yang dapat disimpulkan mampu mendukung proses pembauran dan integrasi tersebut. Pertama, kesamaan identitas agama (Islam) sehingga memungkinkan terjadi interaksi di hari-hari besar keagamaan. Kedua, pembangunan infrastruktur dan fasilitas umum, seperti pasar dan balai pengobatan yang menjadi media interaksi antara transmigran dan penduduk lokal semakin tinggi. Ketiga, tidak adanya konflik agraria seperti yang berlangsung di tempat lain. Terakhir, kejadian penyelamatan warga transmigran oleh Pasukan Rimba pimpinan Nani Wartabone dari percobaan pembataian yang diprakarsai Permesta, semakin menjadi perekat hubungan antara warga lokal (etnis Gorontalo) dan pendatang (etnis Jawa dan Sunda).

\section{CATATAN}

${ }^{1}$ Surat tersebut ditulis pada tanggal 10 Desember 1951. Jelasnya lihat Inventaris Arsip Kesekretariatan Negara, Kabinet Perdana Menteri tahun 1950-1959, ANRI, No. 3461.

${ }^{2}$ Kepala Kesehatan Transmigrasi yang mengunjungi objek Transmigrasi CTN di Kalimantan Barat, sejak tanggal 22 September sampai dengan 02 Oktober 1953 menyebutkan bahwa dari 9 lokasi penempatan transmigran, 3 lokasi (Tayan, Rawah dan Pakauman) telah ditinggalkan. Sementara 7 lokasi lainnya dalam kondisi memprihatinkan. Pada umumnya mereka memilih kembali ke Jawa atau pindah ke wilaya lain karena tanah di lokasi penempatan tidak cocok untuk pertanian, penyakit endemik malaria yang terus 
mengancam, peralatan pertanian belum di bagikan sepenuhnya dan tunjangan hidup dari pemerintah yang sering terlamabat dibagikan. Berdasarkan kondisi tersebut, sulit dilakukan pemindahan penduduk bersar-besaran sebab minat untuk bertaranmigrasi semakin kecil, karena gambaran yang ada dalam benak calon transmigran adalah kemelaratan dan penderitanan bukan kesejahteraan sebagaimana seharusnya (ANRI, Inventaris Arsip Kesekretariatan Negara No. 3459).

${ }^{3} \mathrm{Pada}$ lembaran terakhir suratnya, Lasahido menegaskan bahwa jika pemerintah tidak memperhatikan kemandirian pangan di wilayahwilayah tersebut maka akan sangat berbahaya. Menurutnya jika Selat Makassar, Flores, dan Banda ditutup oleh pihak lain maka saat itu momen terbaik menaklukan daerah-daerah yang kebutuhan pangannya disuplai melalui jalur tersebut. Dengan demikian maka suatu daerah dan masyarakatnya tidak perlu ditaklukan melalui kekuatan senjata, tetetapihanya dengan beras dan gandum. Oleh sebab itu, soal makanan rakyat di sana, wajib bagi pemerintah untuk memberi perhatian lebih mulai sekarang (ANRI, Inventaris Arsip Kesekretariatan Negara No. 3461).

${ }^{4}$ Terdapat 8 alasan pokok yang dituliskan. Pertama, tanah yang subur di Paguyaman sekitar 200.000 hektar, sebagian besar datar dan sangat cocok untuk lahan persawahan. Hamparan tanah yang luas tersebut hanya sedikit sekali yang sudah berpeghuni; Kedua, di lokasi tersebut banyak pohon besar yang dapat ditebang dan dikirim ke Pulau Jawa yang kekurangan kayu untuk bahan bangunan; Ketiga, terdapat sungai besar (Sungai Paguyaman) yang airnya dapat dialirkan ke lahan-lahan transmigran untuk penananman padi sawah; Keempat, banyak terdapat emas yang terbawah oleh sungai tersebut sehingga dapat dimanfaatkan oleh transmigran untuk menambah penghasilan; Kelima, hasil-hasil perkebunan dan pertanian dapat dengan mudah diangkut ke pelabuahan Paguyaman yang disinggahi oleh KPM dan kapal motor lainnya; Keenam, lokasi tersebut tidak jauh dari laut, sehingga tidak sulit mendapatkan ikan untuk kebutuhan sehari-hari; Ketujuh, di muara Sungai Paguyaman, setiap bulan purnama muncul ikan-ikan kecil yang disebut Nike oleh penduduk lokal; Kedelapan, terdapat banyak hasil hutan yang nantinya dapat dimanfaatkan transmigran sebagai sumber penghasilan tambahan, seperti rotan dan damar (ANRI, Inventaris Arsip Kesekretariatan Negara No. 3461).
${ }^{5}$ Secara umum terdapat 15 jenis bantuan yang diberikan pemerintah kepada transmigran saat itu, baik yang bersifat pinjaman maupun pemberian. Bantuan tersebut berupa pakaian, alat tidur, alat makan, alat dapur, transportasi, perumahan, lahan, tunjangan makan selama 6 bulan, alat-alat pertanian dan pertukangan, serta perawatan kesehatan. Dari 15 item itu, bagi transmigran BRN hanya 4 jenis yang bersifat pinjaman. Sementara, bagi transmigran umum hanya 6 jenis bantuan yang sifatnya pemberian, sisanya adalah hutang yang harus dikembalikan. Perbedaan ini karena penghargaan pemerintah terhadap jasa transmigran BRN semasa perjuangan. (ANRI, Inventaris Arsip Kesekretariatan Negara, No. 3463).

\section{REFERENSI}

Abdullah, Taufik dan Abdurrahcman, Sukri (ed.) (2011). Indonesia Accros Orders: Arus Bawah Sejarah Bangsa, 1930-1960. Jakarta: LIPI Press.

Arsip Nasional Republik Indonesia, "Peraturan Perundang-undangan dirinci menurut Keputusan Presiden periode tahun 1950 No. 1728 dan 1835".

Arsip Nasional Republik Indonesia, "Transmigrasi dan Pembangunan Masyarakat Desa, Inventaris Arsip Kesekretariatan Negara Kabinet Perdana Menteri tahun 1950-1959, No. 3456, $3459,3460,3461,3463,3464,3469,3470$, 3471, 3473, 3474, 3477, 3492”.

Djawatan Transmigrasi (1951). Transmigrasi 1951-1955. Djakarta: Djawatan Transmigrasi.

Gottschalk, Louis (1983). Mengerti Sejarah. terjemahan Nugroho Notosusanto. Jakarta: Universitas Indonesia.

Hauser and Duncon (1958). The Study of Population. Chicago and London: The University of Chicago Prees.

Kementerian Penerangan RI (1953). Republik Indonesia Propinsi Sulawesi. Makassar: Kementerian Penerangan.

Oey, Mayling dan Astika Ketut Sudhana (1982).

"Target-Target Transmigrasi dan

Realisasinya” dalam Hardjono, Joan (ed.), 
Transmigrasi; dari Kolonisasi sampai Swakarsa. Jakarta PT. Gramedia.

Storey, William Kelleher (2011). Menulis

Sejarah: Panduan untuk Mahasiswa. terjemahan Abdillah Halim. Yogyakarta: Pustaka Pelajar.

Suparlan, Parsudi (1972). The Javanese in Surinam: Ethnicity in an Ethnically Plural Society. Illionis: University of Illionis.

Vickers, Adrian (2011). Sejarah Indonesia Modern. terjemahan Arif Maftuhin. Yogyakarta: Insan Madani.

"Dokumen Rencana Pembangunan Jangka Menengah (RPJM) Desa Sidodadi Tahun 2011-2015". 